\title{
Urban Communication: The Uses of Public Space in Riga Historical City Centre
}

\author{
Uǵis Bratuškins, Riga Technical University \\ Sandra Treija, Riga Technical University
}

\begin{abstract}
Expansion of cities and their impact areas extend also the semantic boundaries of urban ecentres, while public open space in the city centres maintain attractivity, especially within the medieval cores. The diverse functional processes that satisfy the needs of all users of urban space in general, on the one hand carry the function of circulation or communication, and on the other - relaxation or recreation. Elements of spatial organization and environment planning essential for the realization of each function differ, and depending on which of the functional processes prevails in the particular place, open space acquires either priority of communication or of recreation.

The paper focuses on the interests and needs of main groups of users of the historical city centre - Riga Old Town, states availability of adequate space, as well as sets the criteria of high-quality public open space.
\end{abstract}

Keywords - Historical City Centre, public open space, Riga Old Town.

\section{Semantics of City Centres in the Contemporary Context}

In spite of the deformations having caused significant changes in the planning structure of the historical parts of many European cities in the $20^{\text {th }}$ century, the scale of the medieval space and the nature of the built-up environment has remained. The most precise historical consistency of the impact of various types of authorities on the city life may be observed by the city skylines [3], where both the secular and spiritual authorities have left distinct spatial dominants, as well as by the planning structure, where 'the clear link between the city ecentre (town hall with the town hall square) and a periphery was spatially manifested by the street network and in character of the buildings' [13]. The poles of the secular and spiritual authorities in the spatial structure of the towns are experssed not only in volumetric terms but also as dominants of public open space - the squares were formed nearby the most significant buildings. Town hall squares and church squares were the first wider public open spaces, while the buildings in the streets linking them created 'a unitary in shape development line, a unique syntagmatic system, based on the coherence of adjacent shapes' [13].

Both activities of public and economic life were bursting in the squares, and becoming diversified by time, separate areas gradually obtained distinct functional characteristics. In European cities, like Mannheim, in the 18th century existed both Cour d'Honneur, Parade Square and Market Square [6]. The syntagms also changed, and, by functions of the squares becoming more heterogeneous and more diverse; the proportion of public activities taking place there increased. Consequently, the significance of the traditional semantic poles in the urban environment diminished, and as 'the total level of semantic precision affects ... the stability of the historical styles of architecture and the form of language discipline', on the one hand, the location of socially significant architectural dominants was no longer linked to the location of the spatial dominants, and on the other hand, this tendency contributed to the forming of new semantic accents in new places [13]. With the development of economic relations between cities and peripheries, impact of towns increased and they became centres of wider regions [1]. Consequently, the role of urban historic ecentres increased in the regional context, and thistendency is particularly important also nowadays, when a significant part of the visitors of public open spaces of the city ecentres are non-residents of them.

Up-to-date social activities burst both in the streets and squares, besides, the functions and social events implemented in the streets are not precisely separable from those implemented in the squares. The number of visitors or participants is expected to become the determining factor for the expansion of a specific event in a particular public open space. More publicly significant is the event, the higher the number of visitors is expected, the greater the public open space is needed. Thus, the semantic precision of the contemporary urban public open space is characterized by the degree of intensity of social activity there. In this context, the syntax between the most widely used public open space is the coherence of the intensity of adjacent public activities.

\section{The Functionality of Public Open Spaces in Riga} Old Town in the Context of Interests of Users

The level of functionality of the public open space depends on the differentiation of its separate structural elements. The public open space system is the spatial equivalent of urban functional links and urban landscape. The user of urban environment gets an impression of the overall character of the city from public open space. Functional accuracy or communicability is one of the indicators of urban quality. Its suitability for social activities and recreation in turn is characterized by recreativeness, which includes a wide spectrum of aspects: functional diversity, quality of street furniture and equipment, quality of architectural and landscape elements, and public safety. The basis for the visually appealing and diverse public open space system is its functional differentiation, which allows to develop the most appropriate activities in each particular public open space or group of them.

Up-to-date Riga Old Town is the oldest part of the state capital centre, characterized by intensive multifunctional activity. Its public open space is used by a variety of user groups both on a daily basis and on special occasions (Figs. 1 and 2), whose in- 

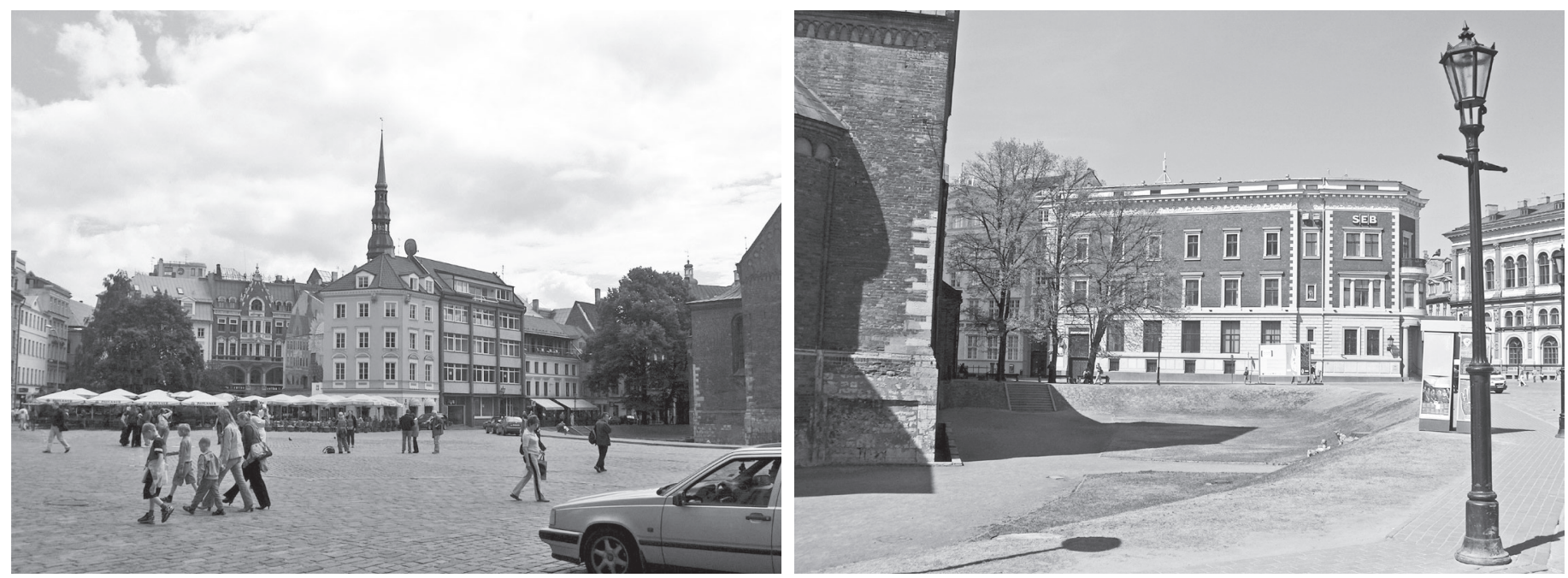

Fig. 1. Capacity of Riga Old Town public open space in daily mode [Picture: U. Bratuškins].
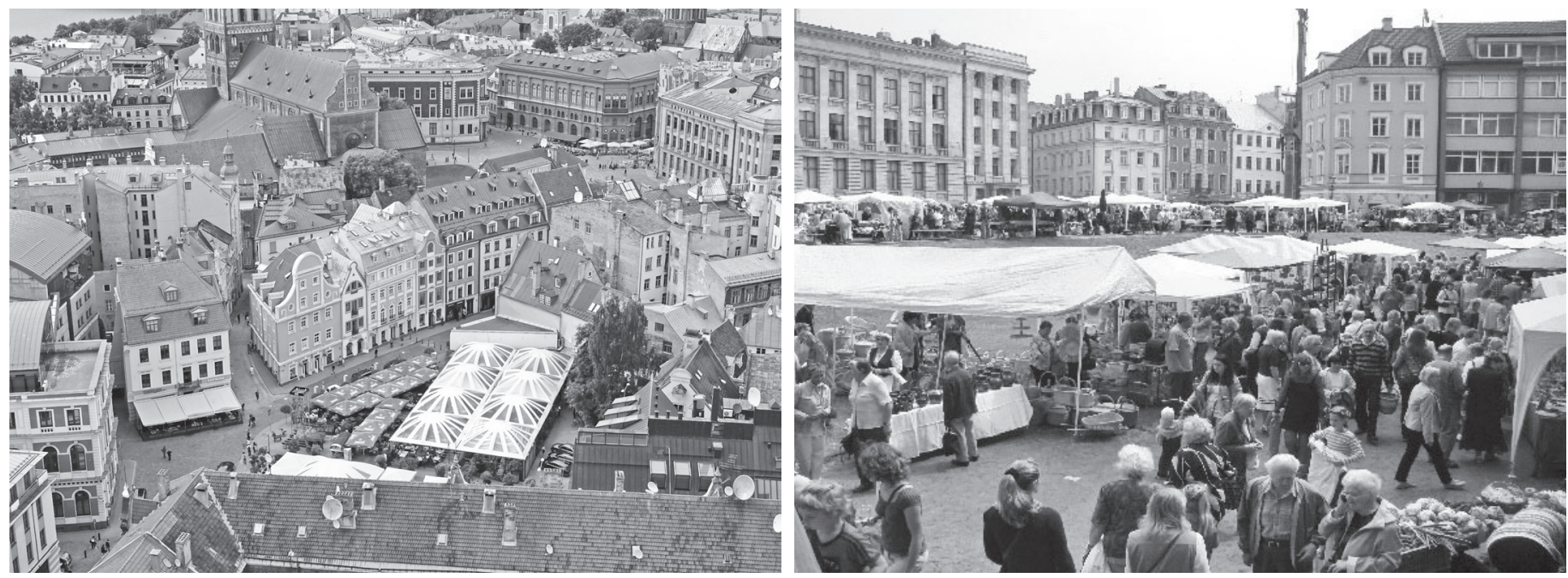

Fig. 2. Usage of Riga Old Town public open space in daily and festive mode [Picture: U. Bratuškins].

terests, xexpectations and needs vary considerably. The quality and long-term sustainability of the recent changes in the structure of the city in the Old Town depend on the place and role of existing and emerging structural elements in the common system in the contemporary context. In general, the Old Town is one of the most popular visiting places of the inhabitants of Riga as well as a popular visitors' destination for local and foreign people. Its role in the future will increase together with growth of significance of Riga in the Baltic and Nordic region. The attractiveness of the Old Town is determined not only by the considerable number of entertaining institutions but also by the attractive network of public open spaces, which allows anyone to choose the most appropriate environmental scale and intensity of activities. Due to the active present urban processes, the Old Town is one of the most intensive areas of transformations of the spatial environment over the last fifty years, despite the fact that the concept of the city ecentre of up-to-date Riga several times exceeds the area of Old Town.
Since with the city ecentre one can understand the place where the life processes of the society get most active [2], [5], the diversity and intensity of use of urban space is increasing from the periphery to the ecentre. The intensity of functional use of different streets and squares of Old Town significantly differs. The area of Doma laukums, which is most actively used for public events, is $9425 \mathrm{~m}^{2}$, and the paving allows different interpretations of the space, providing an appropriate layout and perceptions for both stage and event-type events. The other spatious Old Town squares (Pils laukums - $16035 \mathrm{~m}^{2}$; Jēkaba laukums - $7870 \mathrm{~m}^{2}$, Lìvu laukums $-5000 \mathrm{~m}^{2}$, and Alberta laukums $-1170 \mathrm{~m}^{2}$ ) are mostly focusedon recreation purposes, and therefore are not particularly suitable for socially saturated events. Strēlnieku laukums (the Latvian Riflemen Square), Jēkaba laukums and Alberta laukums also adhere to the outer perimeter of the Old Town and, without being separated from it, do not provide the desired intimacy of public events. 
However, city-scale activities are not the only functional priority of Old Town public open spaces. The spatial environment of Old Town is used by different groups of users, and each of them needs distinct public open spaces, which Old Town not always can offer.

Riga Old Town is the home to around three thousand registered inhabitants, the number of which over the last decade has been relatively stable with a slight upward trend (2851 inhabitants in 2006, 3059 inhabitants in 2010, and 3265 inhabitants in 2014 [10]). In the survey on the quality of life in the historic ecentre of Riga, almost half of the respondents in the Old Town (48\%) indicatedthe lack of yard in their homeplace, or to the fact that it cannot be used in full. The most urgent improvements regarding the quality of the living environment, according to the population, are the necessary improvements of the street furniture of the inner courtyards (94\%) [4]. In terms of the high-density of built-up space and the lack of semi-private open space, the public open spaces in a compact environment should provide a range of functions that are usually expanded in wider areas in both public and semi-public or semi-private spaces. In the Old Town, public open space is the only option for both children playgrounds, recreation spaces for people of all ages, pet-walking and other specific activities related to residential functions.

Another group of Old Town users is school youth. In the Old Town, there are two schools with more than 1000 pupils (1150 pupils in 2017 [7], [8]), and this group of users needs space for specific types of outdoor expression - playgrounds and sportsgrounds. There are no public open spaces like that in Old Town, therefore these activities partly should take place indoors.

There is also a significant number of workplaces in the Old Town - more than 20000 units (21 242 in 2000, 24379 in 2004 and 22593 in 2008 [11]). People working in this part of the city use public open space mostly as communication for getting to workplace and return from it, as well as to meet daily household needs - to make purchases, to visit public utilities and credit institutions, etc. This group of users primary is interested in the fastest and most convenient communicative links, and successful organization of pedestrian, cycling and car traffic. Similar interests are also found in the vast group of the Old Town public open space users, crossing this part of the city in transit day by day.

An important group of Old Town users that directly impacts the quality of public spaces is entrepreneurs whose activities relate to the provision of services, in particular in the field of catering. These entrepreneurs are the most active environmental converters, which, in particular in the warm season, deploy supplementary outdoor business units in the outdoor areas adjacent to their main businesses. It attracts the attention ofvisitors and broadens the range of public activities, promoting the diverse use of the environment and raising the level of recreation options. True, the elements of environmental equipment and amenities used for their business purposes do not always meet the criteria of high-quality design, anyway, the private initiative of this group of users is the driving force in changing the appearance of Old Town public open spaces.
The number of tourists visiting Riga is increasing each year (1 248358 guests used the accommodation services in 2016 [12]). In a survey of tourists' interests in Riga, over $65 \%$ of the respondents indicated that the Old Town was their goal of visiting Riga. In 2017, in the Old Town there were 78 tourist accommodations with several thousands of beds. The hotel sector is increasingly focusing around the city ecentre, and new hotel buildings are being built or renovated, mainly in and around the Old Town.

The need to identify, assess and enhance the recreational potential of public open space achieving wider environmental functional differentiation and higher attractiveness means to define the problems, possibilities and preconditions for its use for the whole territory of the Historical Centre of Riga, including use in different hours and seasons. In order to balance the needs and interests of different groups of users and to promote more diverse use of public spaces, without disturbing the ongoing activities in the adjacent spatial units, it is necessary to differentiate the functional priorities of each of them in the overall public open space system and to identify if there are any possibilities for increasing the proportion of public open space in Riga city centre in future.

\section{Quality Criteria of The Riga Old Town Public Open Space}

Spatial structure is closely related to the semantic precision of the urban environment. Changes in spatial structure are largely related to loss of the overall semantic precision of the city as a common spatial structure. The gravity of interests in a modern city covers location of socially important objects and routes that link them together [9]. In order to characterize the use of urban space, two levels can be distinguished: daily use, when the 'interest gravity' of flows of users is distributed evenly in a wider area, and special use, when individual public buildings or one or more public spaces become the priorities of attendance. In this case, the street network provides access to specific interest objects.

The gathering of visitors for important events and socializing is one of the traditional functions of the public open space [2]. Before reorganizing the existing public open space or creating new systems, it is first and foremost important to assess whether the proposed changes will contribute to or inhibit the activity of public life. Public events are usually related to the influx of a significant number of participants, and in this respect, the suitability of each part of the city to the particular function depends not only on its location in the structure but also on the area and the level of equipment. Although the Old Town public open space system covers different units, the intensity of their use varies considerably.

In the present Old Town, the most intense pedestrian daily flows pass through Kalı̧ku iela, Audēju-Grēcinieku iela, Jēkaba-Šk̆ūņu-Skārņu iela and Vaļnu iela, which connect actively used access to this part of the city from both the ecentre of Riga and Pārdaugava area accross the River Daugava. Smilšu iela and Torņa iela, which stream to the city centre, as well as Jékaba iela, have become active tracks, too. The most prominent public open spaces - Rātslaukums (the Town Hall Square), Doma laukums and Lìvu laukums - lay adjacent to this street system. 
The tendency to intensify development on the existing nonbuilt-up areas is not unequivocal. The demand for public open spaces is steadily increasing in comparison with the previous years, and a well-designed arrangement of the spatial environment aimed at obtaining a composite and aesthetically complete environment is worthwhile. Such an approach does not exclude the construction of new buildings in free places, especially where they appear to be spontaneous, however, every decision to reduce public open space is acceptable only if the functionality and recreativity of public open space is not compromised. The flexible and diverse use of public open space and transformation of separate units are to aim at ensuring the high-quality environment for active public use. The diversity of public open space allows to differentiate events occurring in each separate place, but in the case of wider events, it is purposeful to integrate several units of the urban structure into a single system.

Construction activities, especially if they relate to changes affecting the historic urban ecentres, cause intense discussions, and opinions about the chosen paths usually differ radically. The issue of the Old Town development is not an exception (Fig. 3). It is expected that the Old Town will continue being favourite location for investments and construction, and partly it is possible by optimizing the existing public open space. Prior to spatial transformation, the interests of both individual developers and general public should be thoroughly assessed in each separate case. Priority in the evaluation of development proposals should be given to the criteria for improving the functional differentiation and recreation level of public open space.

Studies show that the environmental quality and the recreational potential of public open space is directly proportional to activities taking place there. The diverse activities contribute to the attraction of visitors to public open space. Based on the survey carried out by the authors of the paper in the period of 2006-2016, a hierarchical scale of criteria has been developed to characterize the interconnections between environmental functionality and public open space activities:

- non-commercial, leisurely access equipment for everyone (benches, etc.);

- $\quad$ outdoor cafes and/or outdoor bars in a visually appealing urban environment;

- outdoor space in a visually appealing urban environment without additional activities;

- $\quad$ place or opportunity to host performances that are observed by visitors;

- $\quad$ place or opportunity to host outdoor attractions where visitors may participate;

- outdoor space without additional activities;

- fixed or mobile outdoor sales outlets;

- $\quad$ sales in premises with shop windows;

- cafes and/or bars in rooms with shop windows without outdoor seating.

The environmental quality most activelyis influenced by the free availability of non-commercial leisure components, as well as the presence of outdoor cafes in a visually appealing urban environment. The impact of these criteria is significantly greater

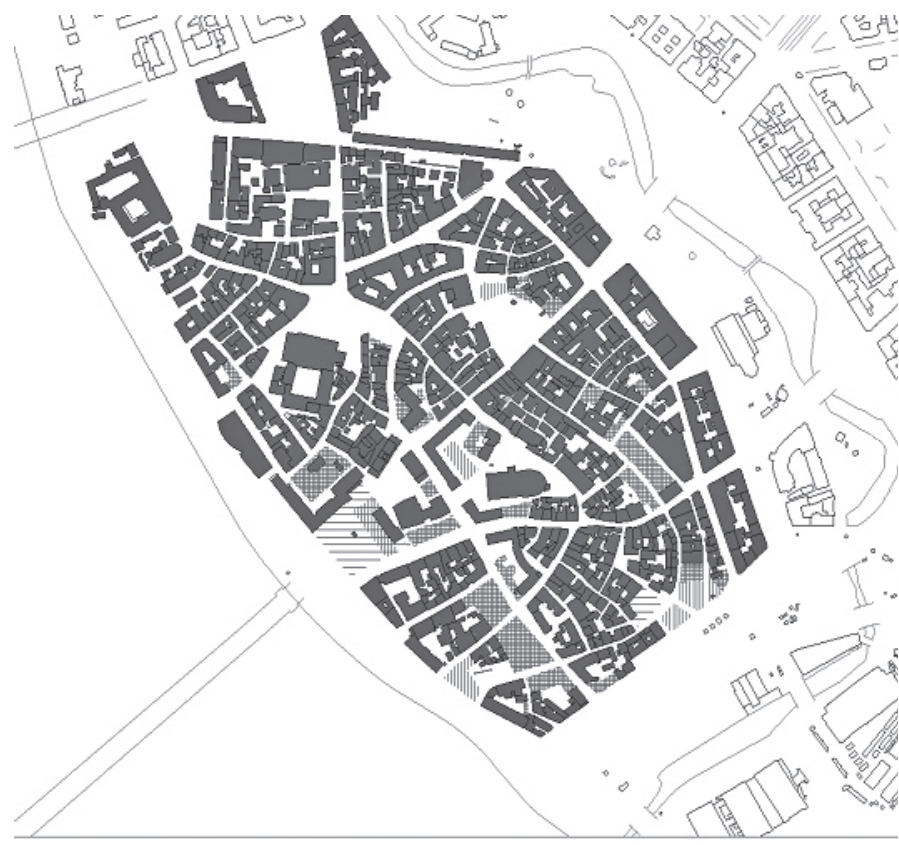

Built-up space

Recent/planned built-up space

Fig. 3. Urban structure of Riga Old Town in the early 21 st century [Figure: U. Bratuškins].

than the ability to hold shows that visitors observe or outdoor attractions in which visitors may participate. The least environmental quality is evaluated in the cases of public functions in premises, which are connected to the outside space only by the entrances, at the same time lacking in visual and functional dialogue between exterior and interior.

\section{Conclusion}

With the growing public interest in leisure opportunities in the centre of Riga, the usage of open recreation space of the Old Town is increasing. Previous practice shows that the public open space of the Old Town operate in two distinct modes - daily and festive, and daily mode at present is facing growing demand for recreational activities. Development forecasts expect this trend continuing, besides, the festive mode will increase. For this reason, besides the communication links, the recreational offer of each public open space unit, which determines the identity of a particular public open space, is becoming more and more important. The recreational offer tends to expand by attracting more and more new visitors to the public open space, thus the daily mode is transformed into a 'casual daily' mode, characterized by a large proportion of recreational activities on a daily basis. This trend is different in different public open space units. Public activities in the Old Town most intensively take place in spatially closed squares, besides Rātslaukums, Doma laukums and Lìvu laukums attract the most number of visitors. According to research data, 
the most intensive pedestrian flow in the Old Town on a daily basis use Kalksu iela and Audēju iela, while the visitors stay longest in Doma laukums, as well as in Lìvu laukums and Vaļnu iela. Obviously, this is facilitated by the diverse functional offer of public open space - Kal̦ku iela and Audejju iela are popular pedestrian transit tracks that provide communicative links, but in Doma laukums and Livvu laukums there is the largest number of outdoor cafes and bars in the Old Town, as well as a recreation area, which, besides communicative links, promotes recreation activities. Kaļku iela, Vaļnu iela and Smilšu iela have a number of shops, cafes and outdoor shops that attract the attention of passersby, thus also offering recreation opportunities.

The needs of the residents of the Old Town within the framework of a comprehensive quality of service cannot be met, and they need to find leisure facilities outside. However, the presence of residents is an important condition for the livability of each city ecentre, and the needs of this group of users need to be, as far as possible, respected and evaluated in the planning and practice.

Creating a public open space system in which differentiated functional priorities are defined for certain public open space units allows to satisfy diverse interests and make the urban environment attractive to visitors in general. The residents of Riga and city visitors want more greenery in the city, more elements of environmental design, non-commercial recreation areas as well as opportunities for active expressions. Each operating mode should have optimal operating conditions, using both stationary and mobile equipment. The fact that at separate events the capacity of the public open space of the Old Town reaches the peak indicates to the need of extending the public open space recreation system outside the borders of Old Town. The expanded public open space system includes the City Canal Landscape Circle and the Boulevard Circle, behind which a high intensity built-up area begins with a relatively small proportion of recreational public open space. The public open space system should be developed also in the direction accross the River Daugava, including neighbouring parks, and historic timber building block in Ägenskalns area.

High quality development of public open space is possible by implementing purposeful functional differentiation, considering the specific features of each unit and reserving the necessary areas for expected activities. In order to increase the environmental attractiveness, special attention should be paid to the extension of the spectrum of recreational functions and activities, which would increase the potential of recreation space. According to the research data, the development of public open space is expected to take place in two main directions:

- inventory and functional intensification of the existing spatial potential of the Old Town, providing different modes for different activities and, whenever possible, maximizing the use of internal courtyards for public events;

- extension of the public open space system beyond the boundaries of the Old Town.

Within reasonable communication links, in the most significant public open space units of Riga Old Town, the recreational offer is not sufficient. Due to the limited development options, more attention should be devoted to the development of a set of mobile outdoor furniture especially designed for the Old Town needs, which, coupled with the gradual increase in the number of visitors, would ensure their growing needs for various recreational opportunities. The diverse and high-quality urban environment is the most important challenge of public open space system in the city.

\section{REFERENCES}

1. Briṇkis, J. Rajonu centru un pilsētu teritoriālās struktūras un to tieces lauki. RTU zinātniskie raksti : Arhitektūra un būvzinātne. Rīga: RTU, 2003. 23.-27. lpp.

2. Gehl, J. Life Between Buildings : Using Public Space. Copenhagen: Arkitektens Forlag, 2001. 202 p.

3. Holcmanis, A. Vecrīga - pilsètbūvniecības ansamblis. Rīga: Zinātne, 1992. 256 lpp.

4. Iedzīvotāju aptauja par dzīves kvalitāti Rīgas vēsturiskajā centrā un tā aizsardzības zonā. Vecpilsēta [tiešsaiste 10.11.2017]. http://www.sus.lv/ sites/default/files/media/faili/rvc_az_atskaite_vecpilseta_29102014_2.pdf

5. Melbergs, G. Dažas Rīgas centra rekonstrukcijas problēmas. Latvijăs PSR arhitektūra un pilsētbūvniecība. Rīga, 1987. 86.-100. lpp.

6. Pozo, A. G. Public Open Spaces : Flexibility of Their Uses in Historic and Vernacular Environments [tiešsaiste 10.11.2017]. https://www.icomos.org/ monumentum/vol18-19/vol18-19_18.pdf

7. Rīgas Centra daiḷamatniecības pamatskola [tiešsaiste]. Rīgas Domes izglitības, kultūras un sporta departaments [skatīts 10.11.2017]. http:// dati.e-skola.lv/Iestade/CDAPS

8. Rīgas Valsts 3. Ģimnāzija [tiešsaiste]. R̄̄gas Domes izglitības, kultūras un sporta departaments [citēts 10.11.2017]. http://dati.e-skola.lv/Iestade/ RV3G

9. Roze, A. Pilsētas publiskā telpa. Latvijas Arhitektūra. 2002, Nr. 4 (42), 104. lpp.

10. Statistika par iedz̄ivotāju skaitu Rīgas apkaimēs [tiešsaiste]. Apkaimes [skatīts 10.11.2017]. http://www.apkaimes.lv/stat/iedzivotaju_skaits/

11. Statistika par nodarbinātību Rīgas apkaimēs [tiešsaiste]. Apkaimes [skatīts 10.11.2017]. http://www.apkaimes.lv/stat/nodarbinatie/

12. Statistika par tūristu skaitu [tiešsaiste]. Centrālā statistikas pārvalde [skatîts 10.11.2017]. // http://www.csb.gov.lv/statistikas-temas/turismsgalvenie-raditaji-30321.html

13. Strautmanis, I. Dialogs ar telpu. Rīga: Liesma, 1977. 136 lpp.

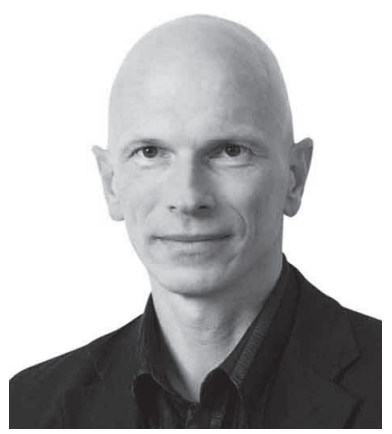

Uğis Bratuškins, Dr. arch., is currently an architect (b. 1961), Professorat Riga Technical University, the Dean of the Faculty of Architecture. He received the degree of Master of Architecture in 1994 and the degree of Doctor of Architecture in 2006. Since 1984, he has been a practicing architect with the design bureau Komunālprojekts Ltd. and Sestais Stils Ltd. He is a member of the Latvian Association of Architects. $\mathrm{He}$ is an author and co-author of many public and dwelling buildings in Riga and other towns of Latvia. His major projects are Renovation of Riga Town Hall Square (Riga City Council Building and Extension, Museum and Chamber Music Hall building The House of the Black Heads, Office buildings), interiors of the Faculty of Social Sciences of University of Latvia. He is a member of Editorial Boards of such journals as Architecture and Urban Planning (Riga, Latvia), Journal of Architecture and Urbanism (Vilnius, Lithuania), Landscape Architecture and Art (Jelgava, Latvia) and Journal of Sustainable Architecture and Civil Engineering (Kaunas, Lithuania). He is an expert at Fondazione Romualdo Del Bianco (Florence, Italy) and Slovenian Research Agency (Ljubljana, Slovenia). $\mathrm{He}$ is the author of more than 60 publications. 


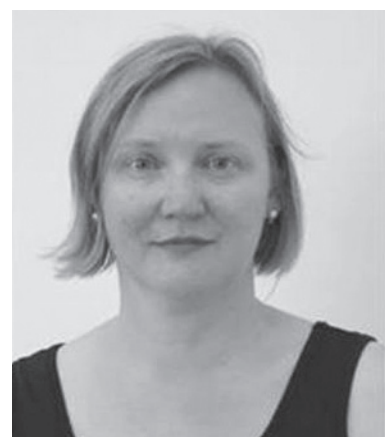

Sandra Treija, Prof., Sandra Treija holds a $\mathrm{PhD}$ in Architecture from Riga Technical University (RTU). She is Deputy Dean in Scientific Work at the Faculty of Architecture, RTU. Her field of research includes sustainable housing, regeneration of neighbourhoods, quality of residential environment, and sustainable urban development Sandra Treija is the author of more than 30 scientific publications and a contributor to Urban Sustainability and Governance. New Challenges in Nordic Baltic Housing Policies, New York: Nova Science Publishers (2009). She is a Member of Editorial Boards of the sjscientific journals Architecture and Urban Planning (RTU), Landscape Architecture and Art (LLU), as well as a member of the Latvian Union of Architects, the European Network for Housing Research, the coordinator of the International Committee for Documentation and Conservation of Buildings, Sites and Neighbourhoods of Modern Movement.

\section{Contact Data}

Uğis Bratuškins

Faculty of Architecture,

Riga Technical University

Adress: 6 Ķīpsalas St., Riga, LV-1048

E-mail: ugis.bratuskins@rtu.lv

\section{Sandra Treija}

Faculty of Architecture,

Riga Technical University

Adress: 6 Ķīpsalas St., Riga, LV-1048

E-mail: sandra.treija@rtu.lv 